ZUZANA SCHEJBALOVÁ, Ph.D.

E-mail: schejbalova@fd.cvut.cz

ALŽBĚTA KVÁšovÁ, Ing.

E-mail: xkvasova@fd.cvut.cz

TOMÁŠ MIČUNEK, Ph.D.

E-mail: micunek@fd.cvut.cz

Czech Technical University in Prague,

Faculty of Transportation Sciences

Konviktská 20, Praha 1, 110 00, Czech Republic

ZDENĚK MAREK, Mgr.

E-mail: zdenda.marek@gmail.com

Police Academy of Czech Republic

Lhotecká 559/7, Praha 4, 143 01, Czech Republic
Safety and Security in Traffic Preliminary Communication Accepted: Feb. 15, 2011

Approved: Mar. 14, 2012

\title{
SIMULATION OF A COLLISION BETWEEN PASSENGER CAR AND CHILD PEDESTRIAN
}

\begin{abstract}
The Department of Forensic Experts in Transportation at the Faculty of Transportation Sciences performed a second set of dynamic passive safety tests of a passenger car (M1 category - Škoda Octavia II) in a child pedestrian collision. The initial and test conditions were similar to those of the first set of tests in September 2009 (Škoda Roomster). The deformations of the contact zones on the frontal vehicle surface were analyzed by a 3D scanning technology (3D handy scanner). Head, thorax and pelvic resultant acceleration, acceleration of knee joint in sagittal direction and contact force on the femoral structure of the dummy (P6 dummy, $1.17 \mathrm{~m} ; 22 \mathrm{~kg}$ ) were measured. The aim of these tests is to provide a detailed description of pedestrian kinematics and comparison of primary and secondary impact seriousness.
\end{abstract}

\section{KEY WORDS}

passenger car, child pedestrian, primary and secondary impact, dummy instrumentation, injury criteria, 3D scanning

\section{INTRODUCTION}

Pedestrian safety is nowadays one of the very important criteria in case of the vehicle safety evaluation. Vehicle certification standards are based on the vehicle frontal part testing with impactors which represent certain body parts of an adult pedestrian. The risk of the impact consequences for children is only tested by the head impactor test [1]. The reason for this stems from many different scientific studies. They proved that the head is the most frequently injured body part in adults as well as in child pedestrians. This conclusion is more significant in case of child pedestrians as it is demonstrated by the two independent sources in
Table 1. A head injury within the frame of polytrauma is usually a predictive injury from the fatality rate point of view. This fact is the predictive factor for the current child pedestrian passive safety certification methodology.

In order to obtain more information on the child pedestrian injury spectrum, a detailed analysis of patients hospitalized at the Anaesthetic Resuscitation Clinic in Motol's Faculty Hospital in Prague in the period from 1996 to 2007 was performed, and contributed to ascertaining the rate and injury seriousness of other children's body parts (see Table 1). Based on the forensic expert's experience, cases which caused similar consequences were selected.

The Faculty of Transportation Sciences performed the second set of three dynamic passive safety tests of a passenger car (category M1 - Škoda Octavia II) vs. child pedestrian collision. The tests were performed at different impact speeds (10; 20; $30 \mathrm{kmph}$ ), analogous to the first set of tests made in September 2009 with Škoda Roomster. The deformations of the contact zones on the frontal vehicle surface were analyzed by 3D scanning technology. Head, thorax and pelvic resultant acceleration were measured on a child dummy P6. The dummy was modified due to the demand on higher number of measuring areas than in the case of the original P6 dummy, which is intended for child restraints testing. The left upper leg was equipped with two strain-gauge halfbridges on the femoral skeleton for the contact force measurement. One uniaxial accelerometer was installed in the knee area for the measurement of acceleration in the sagittal direction.

The initial and test conditions were similar to those of the tests in 2009. The acceleration measuring was made by new equipment. 
Table 1 - Pedestrian injury distribution with respect to certain body region [2, 3]

\begin{tabular}{||l|c|c|c|c||}
\hline \multirow{2}{*}{} & \multicolumn{2}{|c|}{ Source (1) } & Source (2) & Source (3) \\
\cline { 2 - 5 } & Adults & Children & Adults & Children \\
\hline \hline Head & $30.9 \%$ & $56.4 \%$ & $31.3 \%$ & $42.1 \%$ \\
\hline Neck & $4.3 \%$ & $0.0 \%$ & $1.3 \%$ & $4.8 \%$ \\
\hline Unorax & $12.8 \%$ & $7.7 \%$ & $10.2 \%$ & $14.0 \%$ \\
\hline Abdomer extremities & $7.4 \%$ & $12.8 \%$ & $8.1 \%$ & $3.6 \%$ \\
\hline Pelvic & $1.1 \%$ & $0.0 \%$ & $5.6 \%$ & $8.5 \%$ \\
\hline Lower extremities & $5.3 \%$ & $0.0 \%$ & $6.3 \%$ & $10.5 \%$ \\
\hline \hline
\end{tabular}

Source (1) GIDAS/German In-depth Accident Study, file range $N=188$

Source (2) IHRA/PS Accident Data

Source (3) Clinical study made by author, patients of Anaesthetic Resuscitation Clinic in Motol's Faculty Hospital between years 1996 - 2007, Range of patients file $N=146$

Note: Source (3): A total of 479 injuries

\section{EXPERIMENT}

\subsection{Conditions}

With respect to the technical specifications and the possibility of the comparability with the previous measurement, the following initial conditions were formulated:

a) collision of a passenger car (M1 category),

b) P6 dummy, (6 years; $1.17 \mathrm{~m} ; 22 \mathrm{~kg}$ ) which was adapted for the test - mentioned above. (Note: There is no child dummy which is specified for fullscale pedestrian - vehicle crash tests).

c) dummy position: the dummy was facing the approaching vehicle, heel standing in the longitudinal axis of the vehicle (see Figure 1 ),

d) proposed collision speeds: 10; 20; $30 \mathrm{kmph}$,

e) the vehicle is starting to break at the moment of the crash contact.

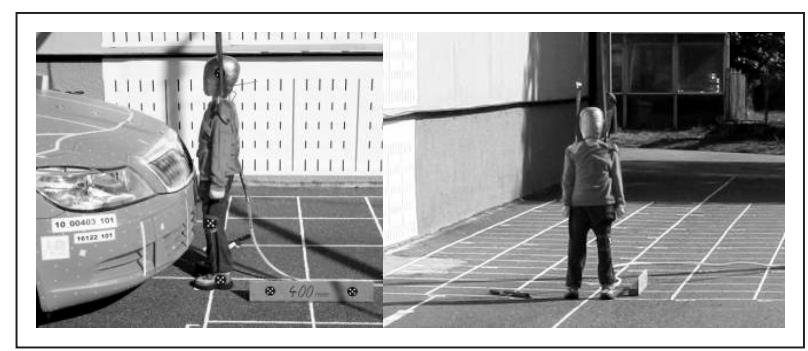

Figure 1 - Initial dummy position

\section{Measured quantities}

- real vehicle speed, vehicle acceleration (3D),

- acceleration time flow of the dummy (according to the dummy instrumentation),

- contact force time flow in femur,

- high speed video recording,

- dimensional characteristics of the process (initial and final location of colliding object),
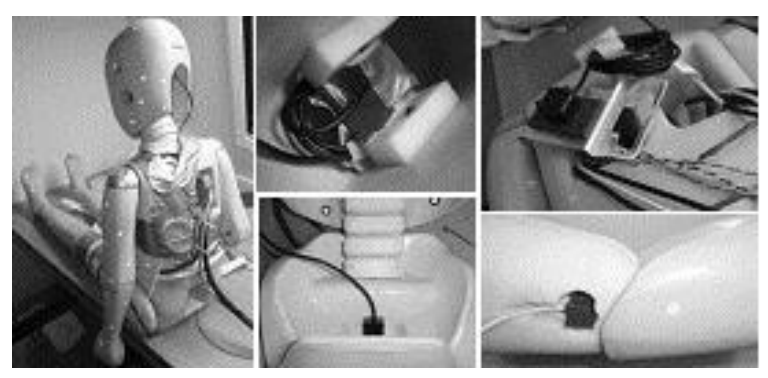

Figure 2 - Dummy instrumentation

- 3D scanning of contact zones after collision and car damage.

Dummy instrumentation (see Figure 2)

- head: 3-axis accelerometer, directions $x, y, z$, 1,000g range,

- thorax: 3-axis accelerometer, directions $x, y, z$, $1,000 g$ range,

- pelvic region: 3-axis accelerometer, directions $x, y$, $z, 500 g$ range,

- knee joint: 1-axis accelerometer, direction x, 500g range,

- upper leg: femoral skeleton - two strain-gauge halfbridges, uniaxial state of stress.

Passenger car Škoda Octavia II, 1.4 MPI

- maximum power: $59 \mathrm{~kW}$

- total displacement: 1,390cm [3]

- curb weight: $\quad 1,255 \mathrm{~kg}$

- the car was equipped with an antireflection coating and impact zones on the bonnet due to the 2003/102/EC directive [4]

\section{TIME COURSE OF THE EXPERIMENT}

Three tests at the real impact speed of $12.2 \mathrm{kmph}$ (test No. 101), $22.4 \mathrm{kmph}$ (test No. 201) and $30.6 \mathrm{kmph}$ (test No. 301) were made. 


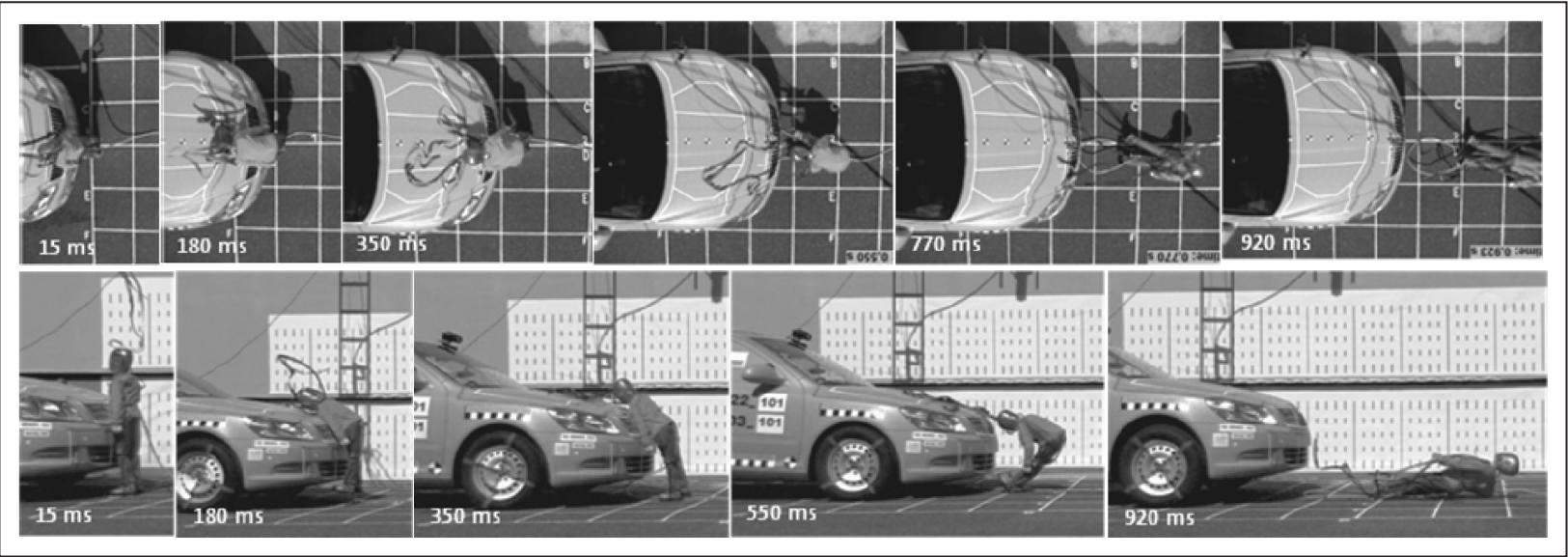

Figure 3 - Test No. 101- video sequence

\subsection{Test No. 101, impact speed $12.2 \mathrm{kmph}$}

Time of the first contact of the dummy with the vehicle: $t_{s 101}=15 \mathrm{~ms}$.

\subsection{Impact speed $30.6 \mathrm{kmph}$}

Time of the first contact of the dummy with the vehicle: $t_{s 301}=3 \mathrm{~ms}$.

\subsection{Impact speed $22.4 \mathrm{kmph}$}

Time of the first contact of the dummy with the vehicle: $t_{\mathrm{s} 201}=9 \mathrm{~ms}$.

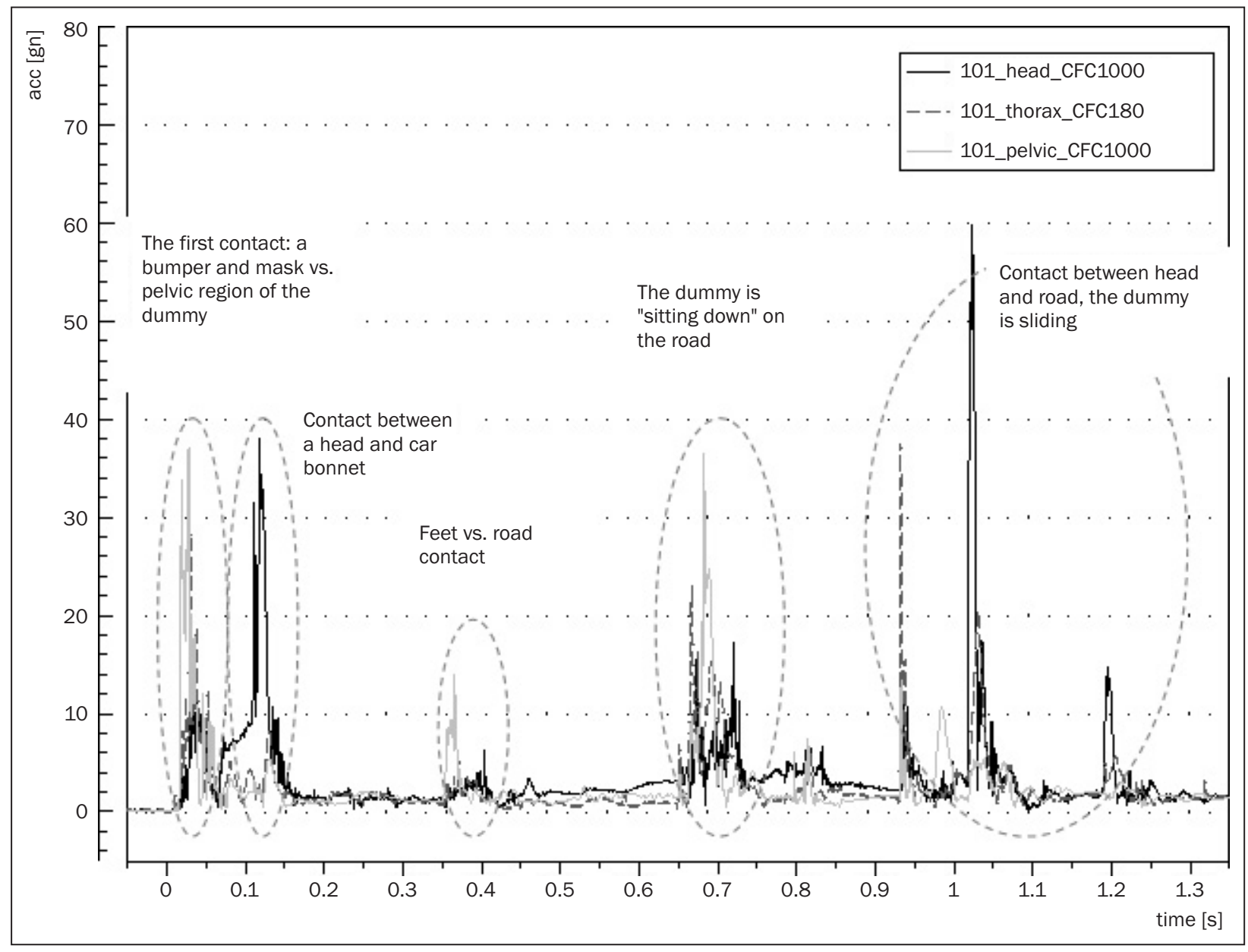

Figure 4 - Test No. 101 - measured acceleration for head (black solid), thorax (dashed) and pelvic (gray solid) 


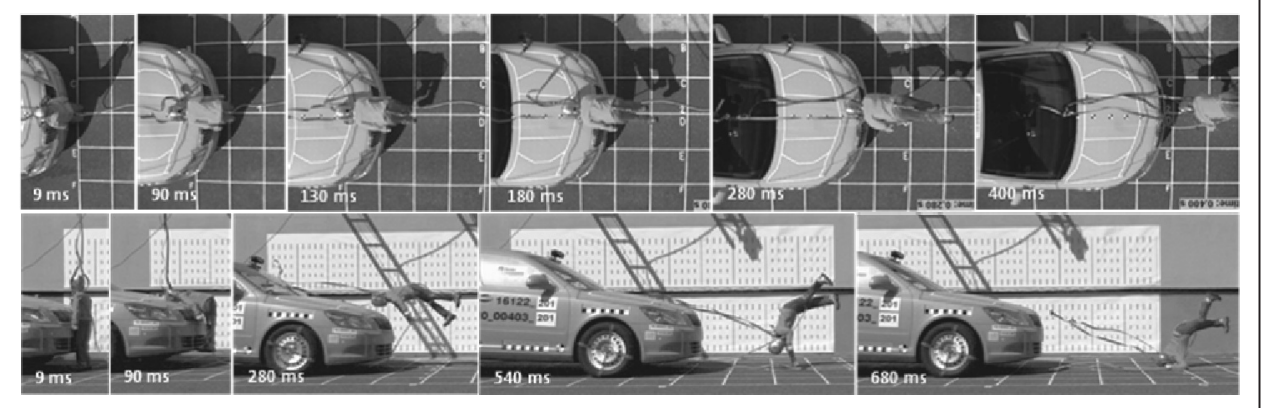

Figure 5 - Test No. 201- video sequence

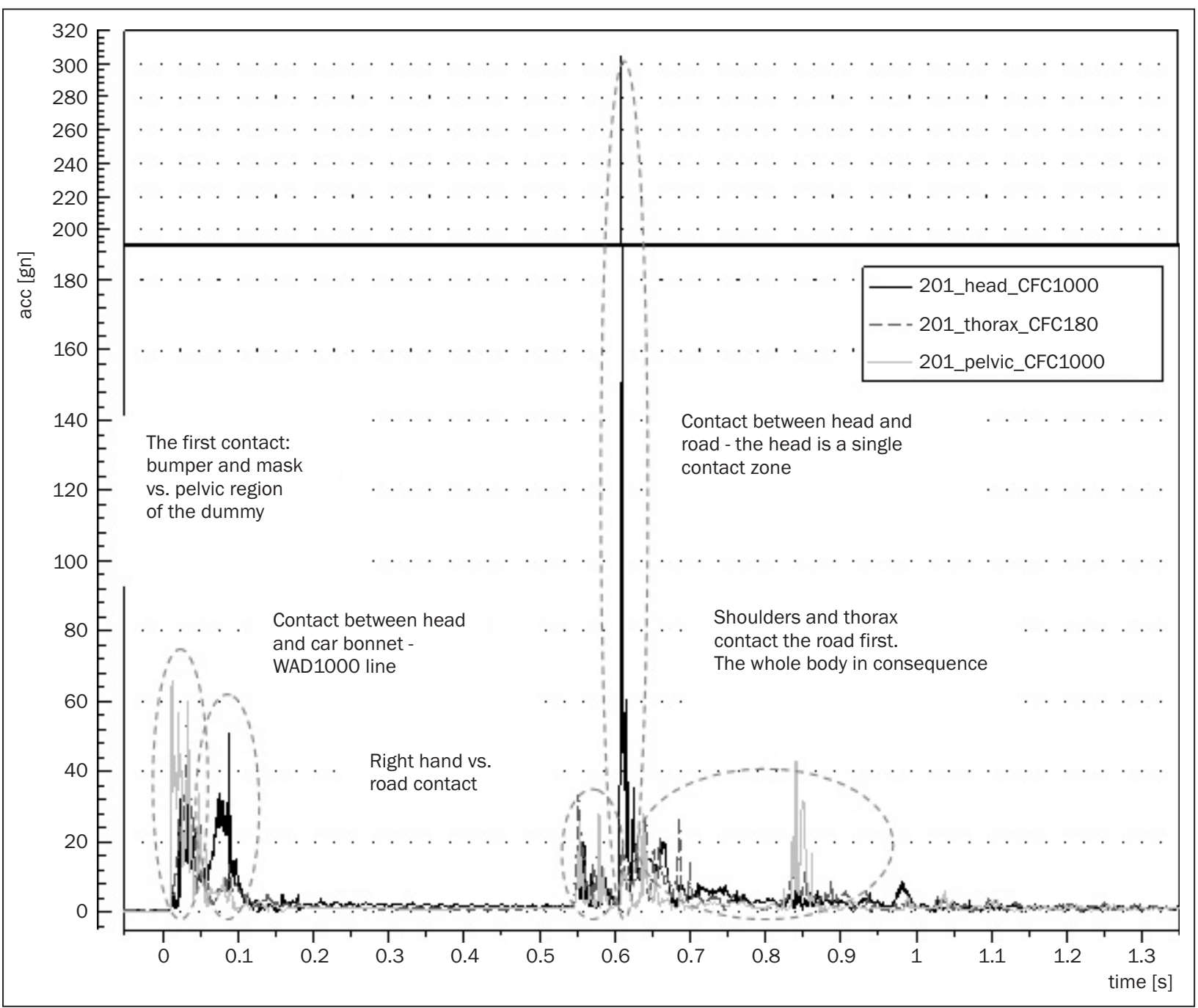

Figure 6 - Test No. 201 - measured acceleration for head (black solid), thorax (dashed) and pelvic (gray solid)

\section{RESULTS}

\subsection{Biomechanical criteria values [5]}

Injury criteria - head: HPC and 3ms

The head performance criterion is defined by the following formula:
$H P C=\left[\frac{1}{t_{2}-t_{1}} \int_{t_{1}}^{t_{2}} a \cdot d t\right]^{2.5}\left(t_{2}-t_{1}\right)$

where $a=$ resultant acceleration in $g, t_{1}$ a $t_{2}=$ time points, which determine the beginning and end of a time interval, where the HPC value is maximal. HPC limit value is 1,000. According to the US standard FMVSS 208 "Occupant crash protection" HPC 15 limit val- 


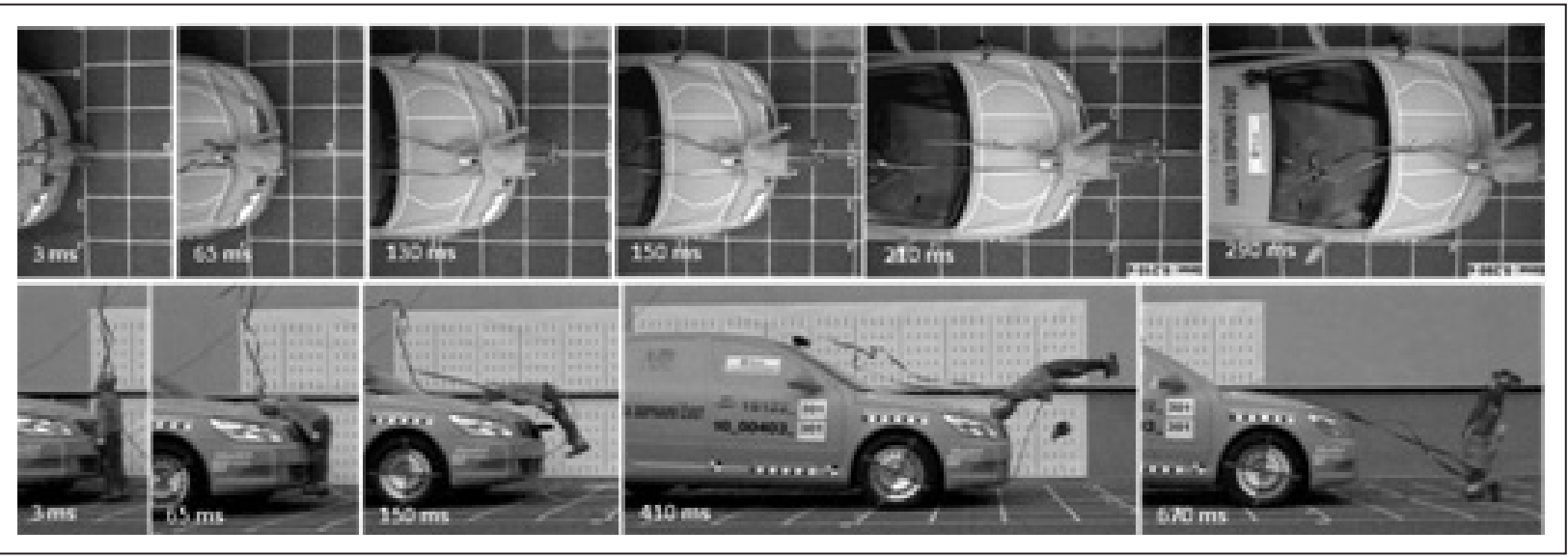

Figure 7 - Test No. 301- video sequence

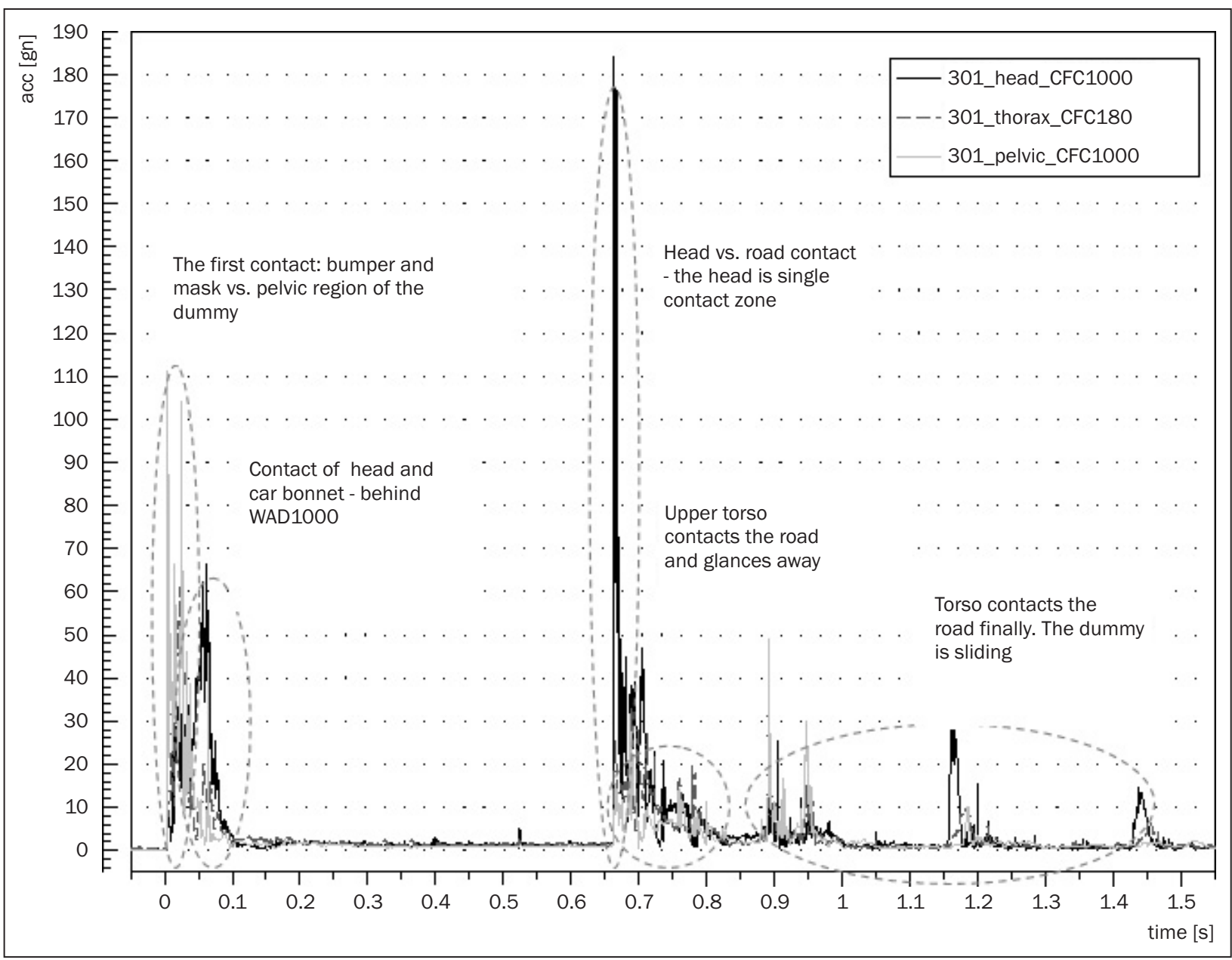

Figure 8 - Test No. 301 - measured acceleration for head (black solid), thorax (dashed) and pelvic (gray solid)

ue in case of a 6-year-old child reaches $700[6]$. HPC measured values are presented in Table 1.

The $3 \mathrm{~ms}$ criterion is applicable not only to the head performance, but also to other body segments. The limit value for head is $80 \mathrm{~g}$. Criterion interpretation: Acceleration higher than $80 \mathrm{~g}$ must not act longer than $3 \mathrm{~ms}$.
According to the US standard FMVSS 208 "Occupant crash protection" $H P C_{15}$ limit value in case of a 6 -year-old child reaches 60g [6]. 3ms measured values (see Table 2):

\section{3ms injury criteria - thorax}

The limit value of this criterion in case of thorax is 60g. According to standard ECE 44 "Child restraints 
Table 2 - Head performance criterion (HPC) and 3ms criterion

\begin{tabular}{|c|c|c|c|c|c|c|c|c|c|}
\hline \multirow{3}{*}{$\begin{array}{l}\text { test } \\
\text { no: }\end{array}$} & \multirow{3}{*}{$\begin{array}{l}\text { velocity } \\
\text { [kmph] } \\
\end{array}$} & \multirow{2}{*}{\multicolumn{2}{|c|}{$\frac{\text { Primary impact }}{\mathrm{HPC}_{15}}$}} & \multirow{2}{*}{\multicolumn{2}{|c|}{$\begin{array}{c}\text { Secondary impact } \\
\text { HPC }_{15}\end{array}$}} & \multirow{2}{*}{\multicolumn{2}{|c|}{$\begin{array}{c}\text { Primary impact } \\
\text { a3ms }\end{array}$}} & \multirow{2}{*}{\multicolumn{2}{|c|}{$\frac{\text { Secondary impact }}{\text { a3ms }}$}} \\
\hline & & & & & & & & & \\
\hline & & {$[-]$} & limit & {$[-]$} & limit & [g] & limit & [g] & limit \\
\hline 101 & 12.2 & 58.2 & $1,000 / 700$ & 135.6 & $1,000 / 700$ & 33.7 & $80 / 60$ & 52.8 & $80 / 60$ \\
\hline 201 & 22.4 & 58.3 & $1,000 / 700$ & 554.8 & $1,000 / 700$ & 26.1 & $80 / 60$ & 49.7 & $80 / 60$ \\
\hline 301 & 30.6 & 251.3 & $1,000 / 700$ & 862.7 & $1,000 / 700$ & 46.6 & $80 / 60$ & 88.7 & $80 / 60$ \\
\hline
\end{tabular}

systems" limit value in case of a 6-year-old child reaches 55g [7]. Measured values (see Table 3):

Table 3 - 3ms criterion - thorax

\begin{tabular}{||c|c|c|c|c|c||}
\hline \multirow{2}{*}{$\begin{array}{c}\text { test } \\
\text { no: }\end{array}$} & \multirow{2}{*}{ velocity } & \multicolumn{2}{|c||}{ Primary impact } & \multicolumn{2}{c||}{ Secondary impact } \\
\cline { 2 - 6 } & & \multicolumn{2}{|c|}{ a3ms } & \multicolumn{2}{c||}{ a3ms } \\
\cline { 2 - 6 } & {$[\mathrm{kmph}]$} & {$[\mathrm{g}]$} & limit & {$[\mathrm{g}]$} & limit \\
\hline \hline 101 & 12.2 & 13.6 & $60 / 55$ & 19.3 & $60 / 55$ \\
\hline 201 & 22.4 & 38.9 & $60 / 55$ & 21.7 & $60 / 55$ \\
\hline 301 & 30.6 & 50.9 & $60 / 55$ & 22.9 & $60 / 55$ \\
\hline \hline
\end{tabular}

$a_{\text {max }}$ injury criteria - pelvic

The maximum acceleration value must not exceed $130 g$ (see Table 4).
Table 4 - 3ms criterion - pelvic

\begin{tabular}{||c|c|c|c|c|c||}
\hline \multirow{2}{*}{$\begin{array}{c}\text { test } \\
\text { no: }\end{array}$} & \multirow{2}{*}{ velocity } & \multicolumn{2}{|c|}{ Primary impact } & \multicolumn{2}{c||}{ Secondary impact } \\
\cline { 2 - 6 } & & \multicolumn{2}{|c|}{$a_{\max }$} & \multicolumn{2}{|c||}{$a_{\max }$} \\
\cline { 2 - 6 } & {$[\mathrm{kmph}]$} & {$[\mathrm{g}]$} & limit & {$[\mathrm{g}]$} & limit \\
\hline \hline 101 & 12.2 & 37.1 & 130 & 36.6 & 130 \\
\hline 201 & 22.4 & 65.9 & 130 & 44.2 & 130 \\
\hline 301 & 30.6 & 111.4 & 130 & 39.1 & 130 \\
\hline \hline
\end{tabular}

\section{Femur injury criterion - contact force}

The bending femur tolerance is not strictly defined. In case of adult femur the following bending limits are frequently published: $1.5 \mathrm{kN}$ to $4 \mathrm{kN}$. Levine (2002) [5] published the bending limit value till rupture $3.92 \mathrm{kN}$

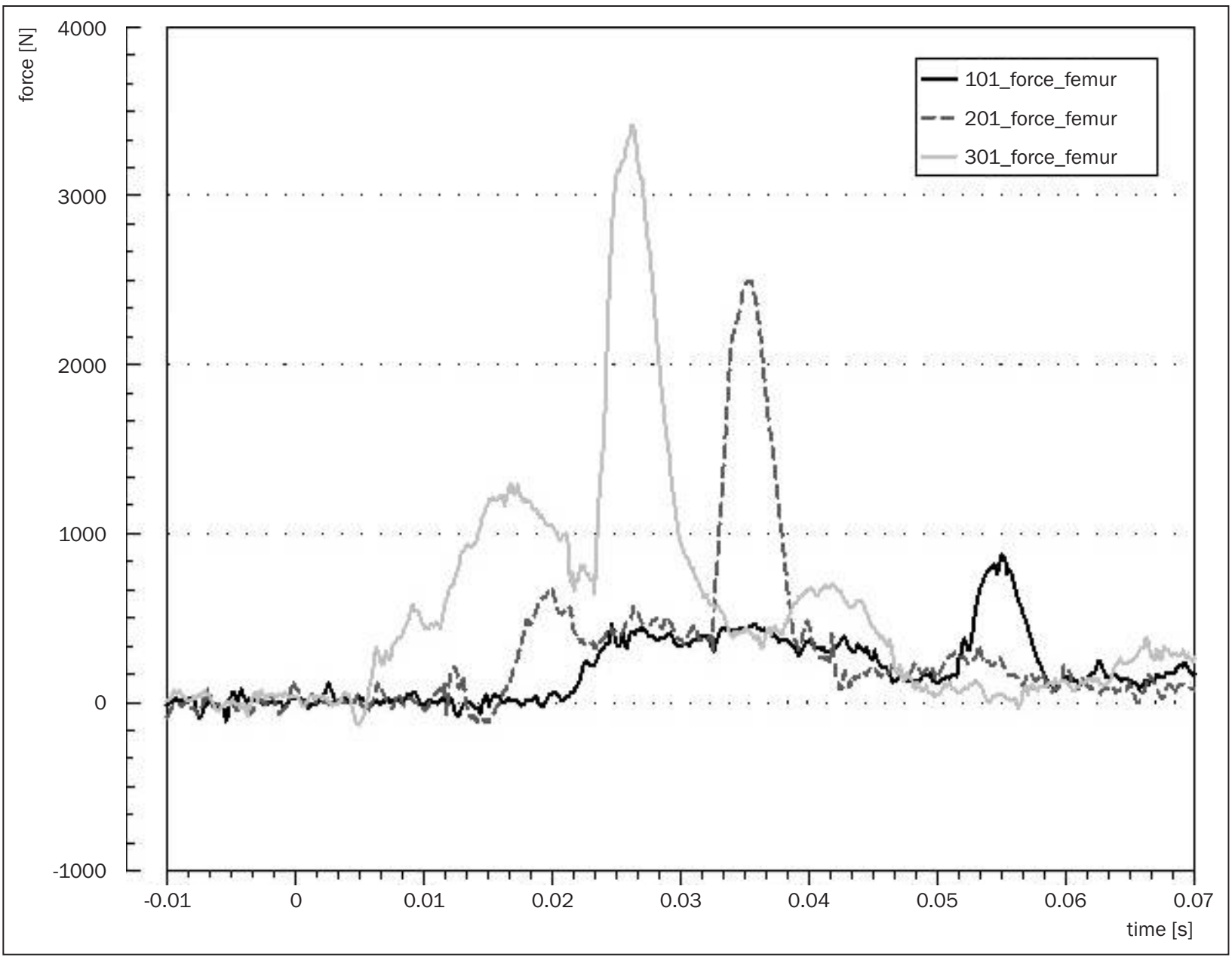

Figure 9 - Femur contact force time course 


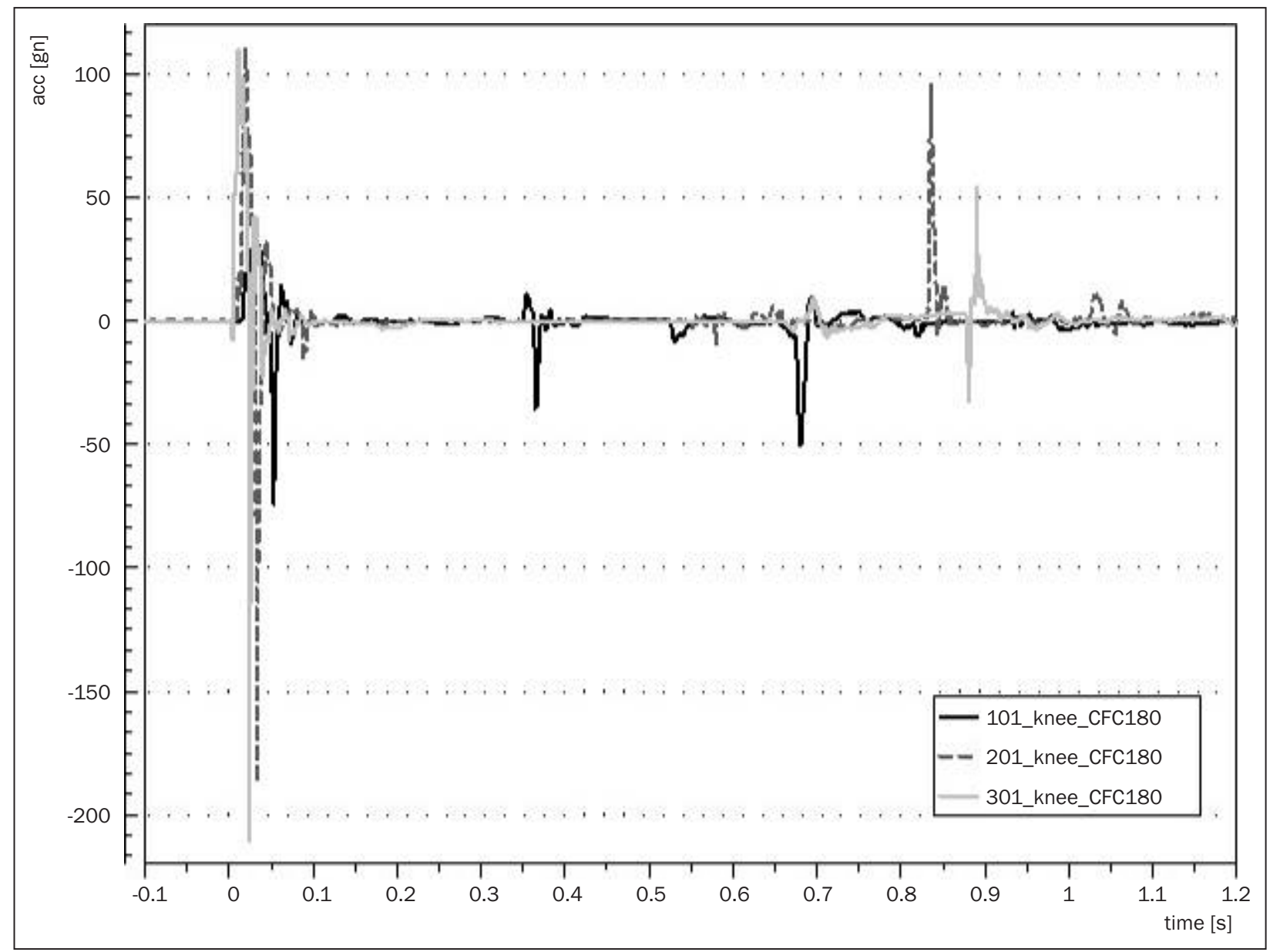

Figure 10 - Knee acceleration time course in $x$ direction

for men and 2.58kN for women. Yamada (1970) published the maximum bending limit till specimen rupture in relation to the donor's age [8,9]. In the group from 20 to 39 years the limit is ca. $2.8 \mathrm{kN}$ in case of $260 \mathrm{~mm}$ [2] femur cortical bone cross-sectional area and bending strength $212 \mathrm{~N} / \mathrm{mm}$ [2]. In children group of around 6 years Yamada published the same level of bending strength, femur has higher level of plasticity and is able to absorb more energy till rupture, crosssectional area of cortical bone is smaller [8, 10]. For the measured values see Figure 9.

Table 5 - Maximum femur contact force

\begin{tabular}{||c|c|c||}
\hline \multirow{2}{*}{ test no: } & \multicolumn{2}{|c|}{ Primary impact } \\
\cline { 2 - 3 } & \multicolumn{2}{|c|}{$F_{\max }$} \\
\cline { 2 - 3 } & {$[\mathrm{N}]$} & $\mathrm{t}[\mathrm{ms}]$ \\
\hline \hline 101 & 877 & 55 \\
\hline 201 & 2,497 & 35.5 \\
\hline 301 & 3,418 & 26.2 \\
\hline
\end{tabular}

\section{Knee acceleration}

Maximum acceleration value must not exceed 170g. The measured values are presented in Table 6.
Table 6 - Maximum knee acceleration in x direction

\begin{tabular}{||c|c|c|c|c||}
\hline \multirow{2}{*}{ test no: } & \multicolumn{2}{|c|}{ Primary impact } & \multicolumn{2}{c||}{ Secondary impact } \\
\cline { 2 - 5 } & \multicolumn{2}{|c|}{$a_{\max }$} & \multicolumn{2}{c||}{$a_{\max }$} \\
\cline { 2 - 5 } & {$[\mathrm{g}]$} & limit & [g] & limit \\
\hline \hline 101 & 74.6 & 170 & 50.5 & 170 \\
\hline 201 & 186.8 & 170 & 96 & 170 \\
\hline 301 & 210.4 & 170 & 54.2 & 170 \\
\hline
\end{tabular}

\subsection{D scanning - 3D data digitalization}

3D scanning is a process of data digitalization; the goal is to express the real object in a virtual (mathematical) way. This method of digitalization is able to record space or solid effectively.

The result of 3D digitalization is "a point cloud" where the position of every single point is detected by a 3D scanner. This type of application in connection to a formulated task allows to record car body damage after a crash test.

Method requirements: mobility of device, limited time for scanning (max. 15 minutes for one scanning series), scanning accuracy (in $0.01 \mathrm{~mm}$ ), reliability of the device, data quality, non-contact scanning, out- 


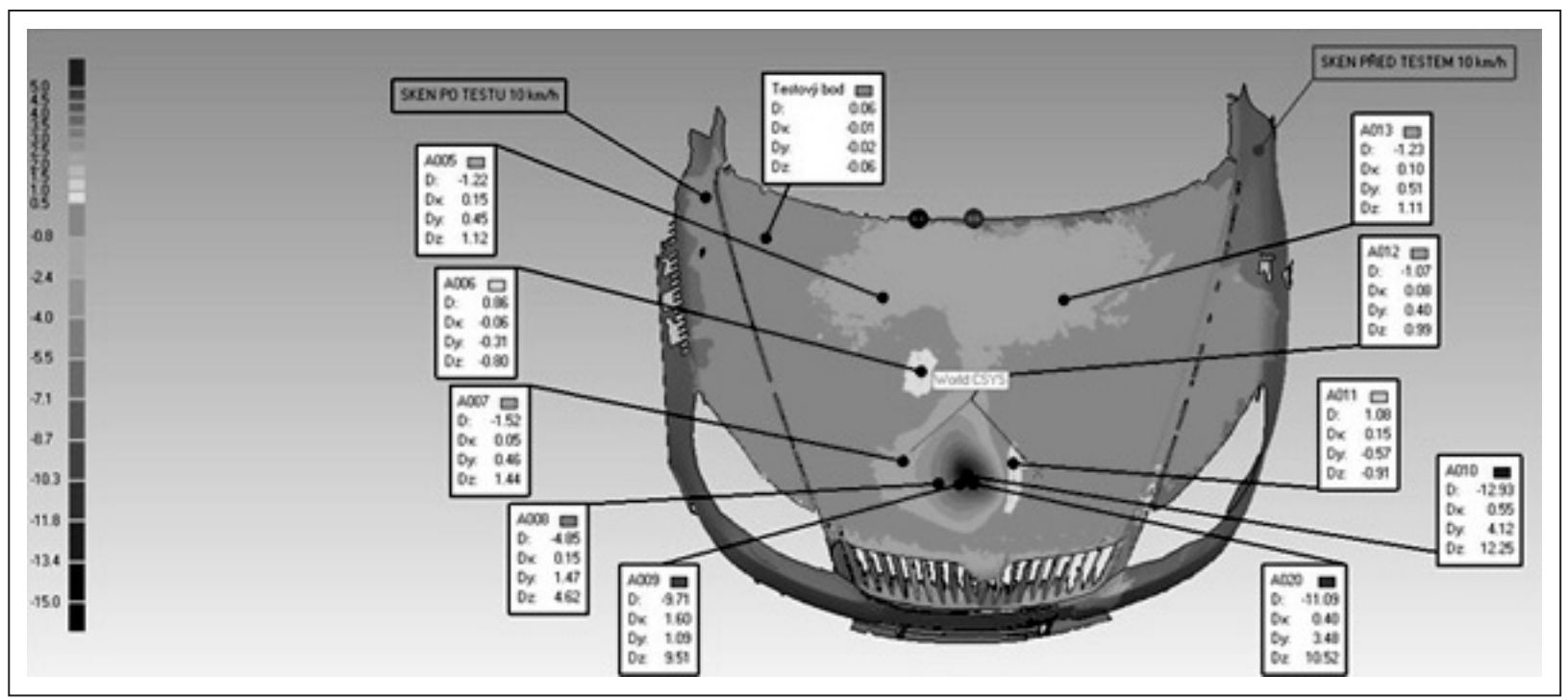

Figure 11 - 3D analysis and deformation map for test $101-12.2 \mathrm{kmph}$

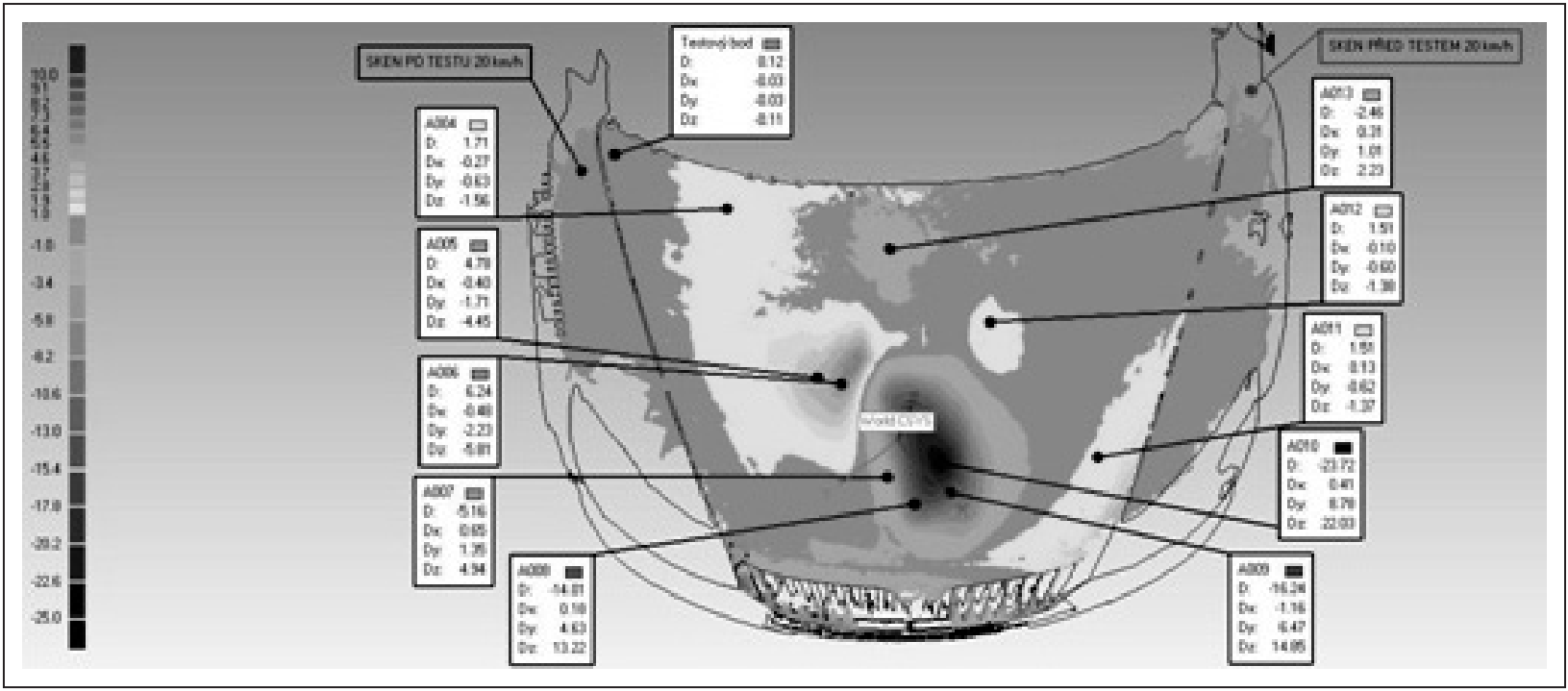

Figure 12 - 3D analysis and deformation map for test $201-22.4 \mathrm{kmph}$

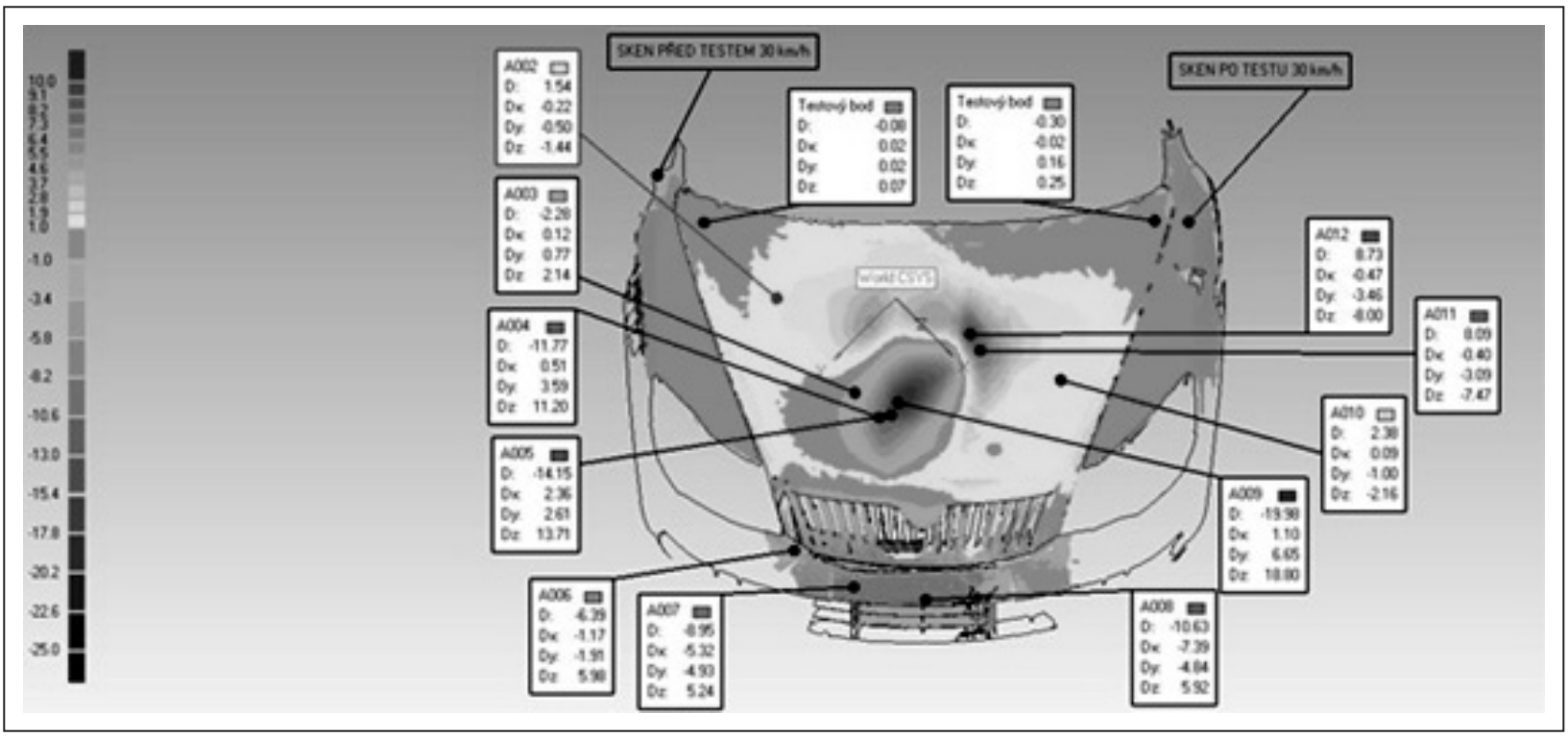

Figure 13 - 3D analysis and deformation map for test $301-30.6 \mathrm{kmph}$ 
door performance, variable lightning conditions, availability of scanned object position change, scanning interruption, "easy" data processing, real time result visualization (data verification).

With respect to the facts mentioned above, Handyscan type MAXScan from CreaForm was chosen for this application. The advantage of this type of scanner is the possibility of a relative motion of the scanner and the scanned object. The scanner identifies the position markings on the scanned object and two cameras record the laser intersection, which is projected on the object.

In case of the car body deformation scanning, parts on vehicle front (bumper, hood, fenders, front grill) were covered with reflex targets. The original vehicle frontal parts were fitted appropriately and scanned because of the consequent comparison with those that were damaged by the crash test. The 3D analysis is based on the 3D surfaces comparison.

The results from test 101/201/301 (12.2 $\mathrm{kmph} / 22.4 \mathrm{kmph} / 30.6 \mathrm{kmph}$ ) show, that the dummy head impact caused plastic deformation of the hood of $13.2 \mathrm{~mm} / 23.7 \mathrm{~mm} / 20 \mathrm{~mm}$ (depth), rear central part of the hood was deflected in test 101 on the average by $1.5 \mathrm{~mm}$. Dummy head contact point is demonstrated by the dark area on the deformation map, lifted area of the hood in test 201/301 reached a maximum of $6.7 \mathrm{~mm} / 8.8 \mathrm{~mm}$

\section{DISCUSSION}

\subsection{Head injuries}

Neither Head Performance Criteria (HPC), nor 3ms injury criteria limit value was exceeded in the primary head impact for all the performed tests. The head contacted the car bonnet behind the WAD1000 line.

The values of the biomechanical criteria are several times higher for the secondary impact than for the primary one. The limit value for the secondary impact was only exceeded in case of test No. 301 (30.6 kmph); the $3 \mathrm{~ms}$ criterion was in this case exceeded by $10 \%$. According to the US standards (FMVSS 208 "Occupant crash protection"), the value of HPC15 exceeded also the defined limit (limit 700) for a 6-year-old child.

Based on the test and video analysis, and the analysis of the secondary contact with the road surface, it is obvious that neither HPC value nor the $3 \mathrm{~ms}$ criteria represent objectively the seriousness of the secondary impact. The reason for this lies probably in the mechanism of dominating flexion and extension motion in the neck spine and head skidding on the road surface. This conclusion corresponds with the previous experiments made in 2009 and with literature cited below $[9,11]$

\subsection{Thorax injuries}

The limit value of $3 \mathrm{~ms}$ criteria for a 6-year-old child thorax (55g according to EHK 44) was not exceeded in any performed test. This value is close to the limit in test No. 301 for the primary impact. For the secondary impact, there is no critical acceleration because of the kinematics of the pedestrian after the collision. The secondary contact took place mostly via head and neck.

\subsection{Pelvic area injuries}

The maximal acceleration limit amax $130 \mathrm{~g}$ was not exceeded in any performed test for the primary or for the secondary impact. The pelvic area is the point of the first contact with the car front end, which can be clearly seen from the graphic presentation of the acceleration and video records made by a high-speed camera. The highest acceleration values for the pelvis area were measured at the primary contact. There is a presumption of abdominal organs contusion and risk of pelvic fracture (symphysis pubic). The pelvic and knee area were the most loaded parts of the body within the experimental series.

\subsection{Knee injuries}

The limit value of the maximal acceleration for knee (170g) was exceeded in test No. 201 and 301 (primary impact). Injury of knee joint or a fracture of a crus (on epiphysis or metaphysis) can be expected.

\subsection{Femur contact force}

The limit value of the maximum contact force on the femoral skeleton is not exactly defined [10, 12]. On the basis of the research, we can say that the average biomechanical limit for the contact force was exceeded at the primary impact in test No.301. In this case a femur fracture can be predicted. The impact force on the femoral skeleton was calculated from the axial strain with the knowledge of the material properties.

\subsection{Secondary impact remarks}

HPC seems to be an indicator of the secondary impact seriousness regarding the fact that in all the tests it reached higher values than in the primary contact with the vehicle frontal part. An interesting observation is that in case of other body parts the results were inverse - the primary impact was the one with the more serious consequences regarding the biomechanical criteria values calculated for the dynamic impacts of certain body parts in the direct interaction with the vehicle frontal part. 


\section{CONCLUSION}

The CTU in Prague, the Faculty of Transportation Sciences performed the second set of dynamic passive safety tests of a passenger car (Škoda Octavia II) collision with a P6 dummy. Particular conclusions and findings are in the discussion part of this paper.

The performed tests show that the head biomechnical criteria were not exceeded within the head contact with the vehicle frontal part. In case of the secondary collision, the head biomechanical criteria based on the linear acceleration detection are not a sufficient predictor for the serious injury occurrence, therefore, angular acceleration should be detected as well.

There is no high risk of thorax serious injury. In case of pelvic, we can expect serious injury occurrence especially in the primary contact above $30 \mathrm{kmph}$. The knee region is threatened by the primary contact with the vehicle frontal part as well as femur. From the measured data we can predict high risk of femoral fracture in contact speed above $30 \mathrm{kmph}$.

Nevertheless, from the results it is obvious that it is necessary to focus on action of force on the upper and lower leg at the primary contact and the necessity of the force moment and acceleration measurement on the neck of the dummy - for the reasons of analysing the secondary impact seriousness. It is a very complex issue which requires further research, for example to identify the factors that can significantly influence the post-crash kinematics and the secondary impact and perform the numerical analysis of the response to factors variation.

\section{ACKNOWLEDGEMENT}

This contribution is supported by MSM6840770043, Škoda Auto, a.s., TÜV SÜD Czech s.r.o., A.L.C.Z. a.s., Solid Vision s.r.o.

ZUZANA SCHEJBALOVÁ, Ing., Ph.D.

E-mail: schejbalova@fd.cvut.cz

ALŽBĚTA KVÁŠOVÁ, Ing.

E-mail: xkvasova@fd.cvut.cz

TOMÁŠ MIČUNEK, Ing, Ph.D.

E-mail: micunek@fd.cvut.cz

České vysoké učení technické v Praze,

Fakulta dopravní

Konviktská 20, Praha 1, 110 00, Česká republika

ZDENĚK MAREK, Mgr.

E-mail: zdenda.marek@gmail.com

Policejní akademie České republiky

Lhotecká 559/7, Praha 4, 143 01, Česká republika

\section{ABSTRAKT}

\section{SIMULACE KOLIZE OSOBNÍHO VOZIDLA S DĚTSKÝM CHODCEM}

Ústav soudního znalectví $v$ dopravě Fakulty dopravní provedljiž druhou sérii dynamických testů pasivní bezpečnosti dětského chodce při kolizi s osobním vozidlem (kategorie M1 - Škoda Octavia II). Počáteční podmínky testů byly obdobné jako v prípadě první série testů, která byla provedena v záři 2009 s vozidlem Škoda Roomster. Kromě výsledného zrychlení hlavy, hrudníku a pánve, bylo detekováno i jednoosé zrychlení kolene $v$ sagitálním smèru a kontaktní síla na stehenni skelet figuríny (figurína typu P6, 1,17m, $22 \mathrm{~kg}$ ) a byla analyzována i velikost deformace prídě vozidla pomocí 3D scanneru. Účelem těchto testů není pouze poskytnout detailní popis kinematiky chodce a porovnání závažnosti primárního a sekundárního nárazu, ale také poskytnout data pro matematickou simulaci nehodového děje.

\section{KLÍČOVÁ SLOVA}

osobní vozidlo, dětský chodec, primární a sekundární náraz, instrumentace, kritéria poranění, 3D skenování.

\section{LITERATURE}

[1] Regulation (EC) No 78/2009 of the European Parliament and of the Council of 14 January 2009 on the type-approval of motor vehicles with regard to the protection of pedestrians and other vulnerable road users, amending Directive 2007/46/EC and repealing Directives 2003/102/EC and 2005/66/EC

[2] Yang J., Yao J., Otte, D.: Correlation of Different Impact Conditions to the Injury Severity of Pedestrians in Real World Accidents, Paper Number 05-0352 http://wwwnrd.nhtsa.dot.gov/pdf/esv/esv19/05-0352-0.pdf

[3] IHRA/PS-WG Pedestrian Traffic Accident Data http:// www.unece.org/trans/doc/2003/wp29grsp/ps-31. doc

[4] Directive 2003/102/EC of the European Parliament and of the Council of 17 November 2003 relating to the protection of pedestrians and other vulnerable road users before and in the event of a collision with a motor vehicle and amending Council Directive 70/156/EEC

[5] Nahum A. M., Melvin J.,W.: Accidental Injury - Biomechanics and prevention, ISBN 0-387-98820-3, Springer, 2002

[6] Legislation FMVSS 208 - "Occupant crash protection"

[7] Legislation EHK44 - Child restraints systems

[8] Yamada, H.: Strength of Biological Materials, Williams \& Wilkins Co., 1970

[9] Valenta, J. et al.: Biomechanics. $2^{\text {nd }}$ revised edition, ISBN: 80-200-0346-0, Academia, 1993

[10] Currey, J. D., Butler, G.: The Mechanical Properties of Bone Tissue in Children, J Bone Joint Surgery, Vol. 57A, No. 6, pp. 810-814, 1975

[11] Currey,J.D.:BoneStrength:Whatare WeTryingto Measure?, Calcified Tissue International, Springer, 2001

[12] McLean A. J., Anderson R. W. G: Biomechanics of Closed Head Injury, Head Injury, ISBN: 0-412-585405, Chapman \& Hall, 1997 